\title{
Perspectives
}

\section{Action Research as a Tool for Professional Development in the K-12 ELT Classroom}

\author{
Luis Javier Pentón Herrera
}

Professional development in the K-12 English language teaching (ELT) classroom is an evolving entity that focuses on meeting the needs of changing demographics and latest educational trends. As a result, many texts have been published with the intention of providing the necessary skills educators need for success in their classrooms and to instruct a highly heterogeneous English for Speakers of Other Languages (ESOL) student population. Nonetheless, many of these resources focus on specific scenarios and instructional approaches that may not be applicable for all ESOL teachers. In this Perspectives article, I propose the incorporation of action research as a practice for K-12 teachers with the vision of empowering them to take control of their professional development and continue improving their instructional practices. Furthermore, I share three examples of how I have used action research in my own practice and the benefits obtained by my ESOL department, my ESOL students, and myself as a teacher researcher.

Le perfectionnement professionnel dans les classes d'anglais du système d'éducation K-12 est une réalité changeante qui cherche à concilier les besoins de l'évolution démographique avec ceux des dernières tendances éducatives. De nombreux textes ont été publiés afin de procurer aux éducatrices et éducateurs les compétences nécessaires à leur réussite en classe, et également dans le but de renseigner une population étudiante hautement hétérogène dans le système d'enseignement de l'anglais à des apprenants étrangers (ESOL). Toutefois, plusieurs de ces sources mettent l'accent sur des scénarios spécifiques et des démarches pédagogiques qui peuvent ne pas convenir à toutes les enseignantes et tous les enseignants ESOL. Dans cet article de Perspectives, je recommande la pratique de la rechercheaction aux enseignantes et enseignants du système d'éducation K-12 en vue de leur permettre de s'autonomiser pour prendre en main leur propre perfectionnement professionnel et continuer d'améliorer leurs pratiques pédagogiques. Je donne également trois exemples de la façon dont j'ai recouru à la recherche-action 
dans ma propre activité et des avantages qu'en ont tirés mon département ESOL, mes étudiantes et étudiants ESOL, et moi-même comme enseignant chercheur.

KEYWORDS: action research, ELs, ELT, ESOL, K-12 classroom

\section{Introduction}

The ever-changing landscape of the English language teaching (ELT) classroom demands more from K-12 educators than ever. Early in the 20th century, teaching English to the foreign-born, as it was known, focused on general didactic principles that ignored important elements of language learning such as culture and first language (L1) literacy (Goldberger, 1920). Throughout the years, different trends and growing populations of English learners (ELs) affected the role and training of teachers of English for Speakers of Other Languages (ESOL). Early work in ELT shows that many of the challenges educators faced in the classroom were associated with teaching English while aligning language and content to the curriculum (Meriam, 1938). In addition, ELs were required to speak only English at school because that was considered one of the best practices for learning English at that time (Meriam, 1938). Recent publications present a more holistic approach to ELT where ESOL teachers are called to become advocates (Linville, 2016; Staehr Fenner, 2014) who provide students with the necessary skills to be academically successful (Calderón, 2007; Echevarría, Vogt, \& Short, 2000) regardless of their literacy skills, native language, or academic background knowledge (Custodio \& O'Loughlin, 2017).

Throughout the many theoretical and practical advances in the ESOL field, K-12 teachers have been tasked with staying current on latest trends and publications (Nation \& Macalister, 2010) regardless of applicability. The ELT field is, without a doubt, one of the most diverse racially, ethnically, linguistically, and academically speaking. Within the ELT field, we find learners and educators who represent most ethnic groups, languages, and backgrounds on our planet. Hence, not all best practices and theoretical knowledge will be germane and helpful for all ESOL teachers and students. In this Perspectives article, I share my vision of action research as a resource that all K-12 ESOL teachers can use independently to improve their instructional practices, learn about their students' needs, and create a teacher-student partnership to improve the ELT classroom environment. My goal is not to discredit or compare other types of research or seminal publications regarding K-12 teacher development in the ELT field, but to empower educators through reflective and active teaching practices. 


\section{Action Research: What Is It, Why Use It, and How to Use It?}

\section{What Is Action Research?}

Mills (2007) explains that action research is "any systematic inquiry conducted by teacher researchers, principals, school counselors, or other stakeholders in the teaching/learning environment to gather information about how their particular schools operate, how they teach, and how well their students learn" (p. 5). Action research is done by teachers with the goal of gaining insight and developing reflective practices that positively influence their students' outcomes and contribute to the improvement of their own educational practices in general. From a practical perspective, action research focuses on a how-to approach and assumes that individual teachers are autonomous, competent, and committed to life-long professional development (Mills, 2007). More important, action research is the tool K-12 teachers can use to research and continue learning about their students' needs, further explore the approaches that work best in their classroom, and find opportunities for growth based on reflective and active practice. Figure 1 summarizes the definition and purpose of action research.

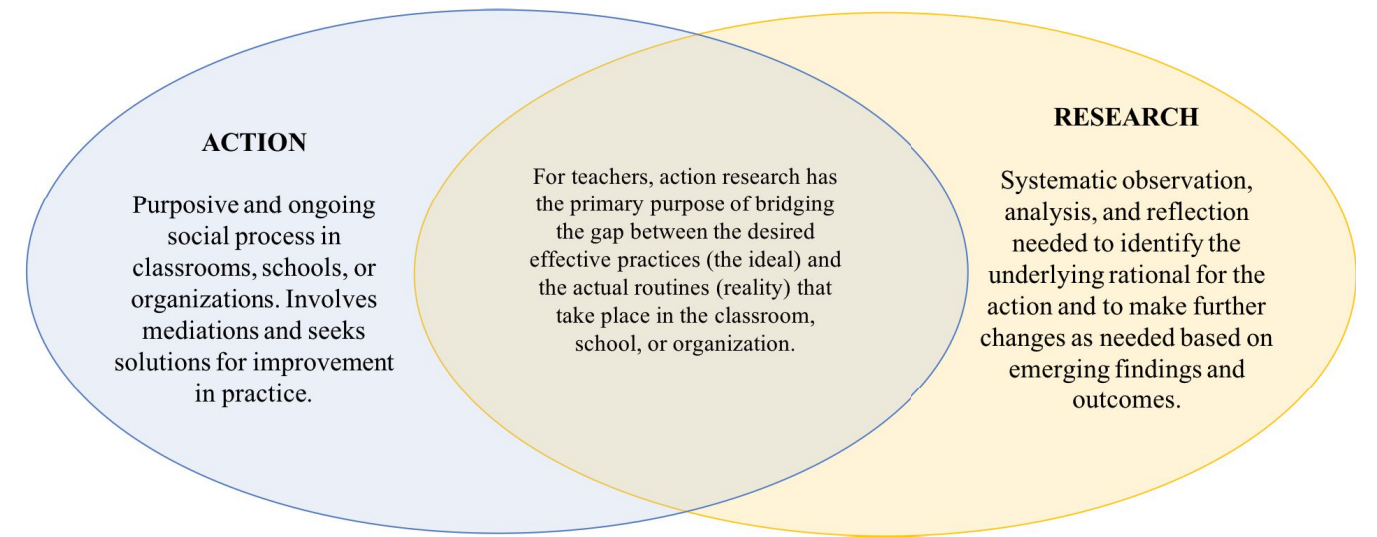

Figure 1: Definition and purpose of action research. Adapted from Burns (2009).

Action research is largely concerned with encouraging teachers to be continuous learners in their classrooms and in their routines. Through prior research, educators make informed and researched choices about what needs to be changed and why. For example, Okigbo, Reierson, and Stowman (2009) share that, through action research, teachers can make educated decisions on how to better help ELs become part of their new society as they learn English. Action research also provides the opportunity to link prior knowledge to new information. For instance, Gilhooly and Lee (2016) discuss the impact action research has in better understanding topics that have been previously researched - such as refugee's educational experiences-because teachers and students work together to find meaning in their findings. Last, action research is relevant and sustains teachers' endeavors and practices. In many universities, action research is being recognized as a necessary part of 
teacher preparation programs (Burns, 2009; Mills, 2007; Volk, 2010) because it provides a foundation for teaching practices that focus on systematically analyzing the effects of teaching on student learning.

\section{Why Use Action Research?}

As an effective educator, we regularly look at how our students are doing and what we can do to make their learning experience better; in essence, that is the purpose of action research. Action research provides an ethical, valid, and reliable nonlinear framework of inquiry - shown in Figure 2-that $\mathrm{K}-12$ educators can use to make a difference and improve their instruction. In this sense, professional development evolves from isolated workshops and teacher trainings - that may or may not be appropriate - to daily evaluations of our own teaching, our students' learning experiences, and opportunities for including realistic solutions that work in our classroom. In a way, engaging in action research shapes our mind-sets and enables us to be reflective of our practices to the point that everything we do in our classroom is guided and supported not only by best practices and prominent works, but by our own understanding of how those theories and practices are beneficial for our learning environment (Bolton, 2010).

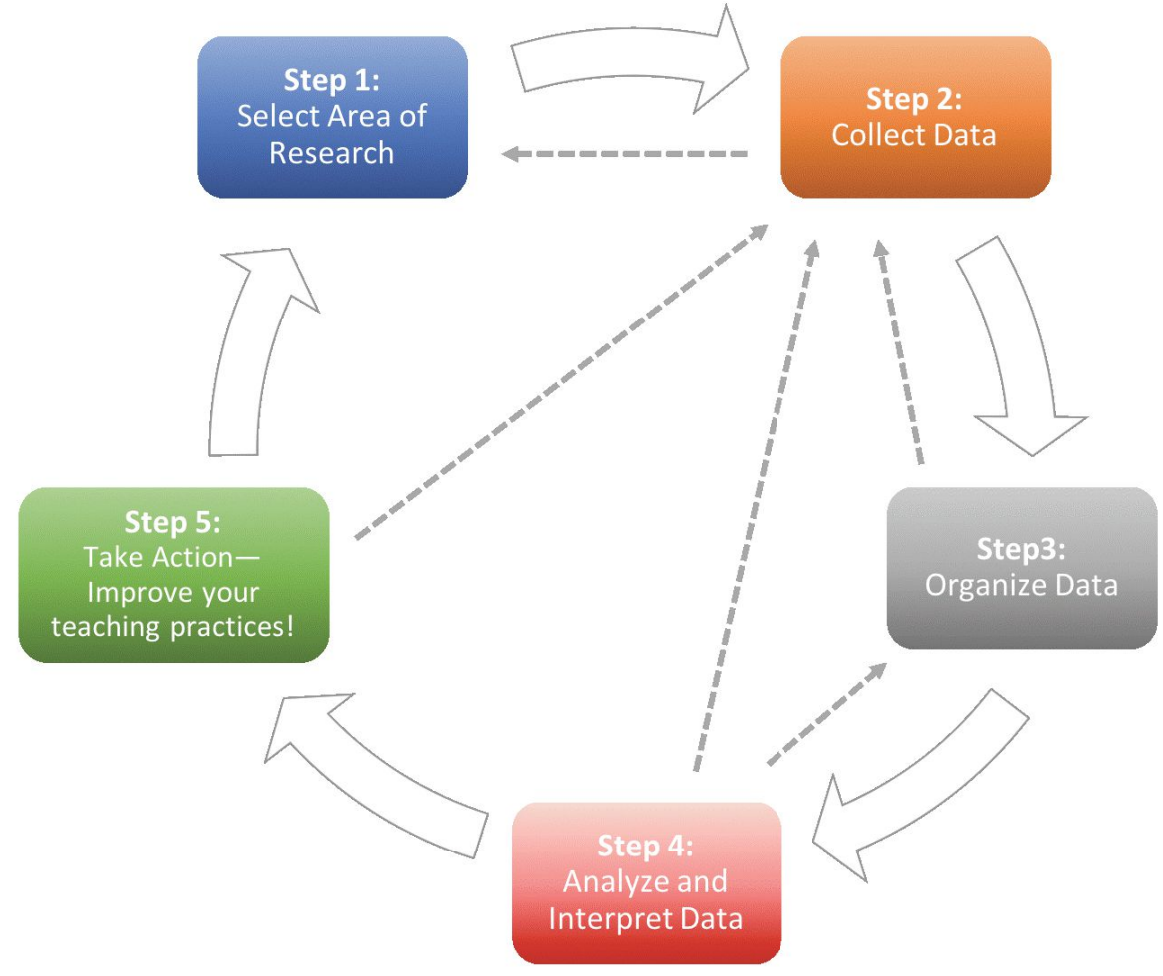

Figure 2: The Action Research Cycle. Adapted from Geoffrey E. Mills (2007). Action research: A guide for the teacher researcher (3rd ed.), p. 17, Upper Saddle River, NJ: Pearson. 


\section{How to Use Action Research?}

There are numerous models, or guides to action (Maxwell, 2003), of the action research paradigm that have been and can be used by teacher researchers (e.g., see Burns, 2009, 2010; Elliott, 2001; Johnson, 2012; Maxwell, 2003; Mills 2007; Sagor, 2000, 2005). However different, all of these models agree that action research needs to be a cyclical and nonlinear process where teachers modify and improve their practices based on emerging findings. Because action research is a flexible paradigm, qualitative and quantitative approaches may be used. Nonetheless, it is important to point out that due to the participatory and responsive nature of action research, a qualitative approach is often found to be more beneficial for educators as our primary purpose is to gain, understand, and communicate knowledge about a specific topic.

Selecting an area of research and ensuring that the topic and research question(s) are appropriate is fundamental at the beginning stage for the success of the action research project. An appropriate topic consists of simply choosing a focus related to the educators' teaching reality of particular interest and that they wish to improve/modify/understand better. Topics may be as simple as teaching present progressive tense or as elaborate as promoting family literacy inside and outside the ESOL classroom. However, a good classroom action research question should be (a) meaningful, compelling, personally and professionally growth-enabling; (b) informative, insightful, and beneficial for learners; (c) leads to taking action; (d) authentic and uniquely created for their particular situation - the use of personal pronouns is encouraged as it reflects their reality; and (e) specific and flexible at the same time allowing exploration and leading to open-ended questions that allow possibilities to emerge. For examples of good action research questions, see Pine (2009), chap. 11.

Another important component of action research is collecting and analyzing data. To collect data, teachers should be open to using different forms of data to increase the validity of their findings. It is generally accepted in action research "that researchers should not rely on any single source of data, interview, observation, or instrument" (Mills, 2007, p. 56). Instead, teacher researchers can choose from different types of tools that gather numerical, descriptive, narrative, and even nonwritten forms of data. Data collection materials may include items such as teacher-made evaluations, student notebooks, attendance records, field notes, video recordings, focus groups, surveys, and many others. To increase validity and reliability of the data collected and analyzed, triangulation is often used in action research. "Triangulation is a process of verification [checking for truth] that increases validity by incorporating three different viewpoints and kinds of information. Data triangulation involves collecting information from different participants and sources, and from different stages in the project" (Nugent, Malik, \& Hollingsworth, 2012, p. 37). Triangulation offers the opportunity to identify 
the weaknesses of each single source while compensating them with the strengths of another. An example of triangulation would be to collect data though a survey, observations, and field notes to later analyze.

Last, when conducting action research, think about and address logistical challenges that might arise before, during, and after this process. Three logistical challenges I have encountered when implementing action research included (a) time required to conduct research, (b) student needs and considerations, and (c) support from school leaders, colleagues, and parents.

\section{Real-Life Applications of Action Research}

After discovering action research, I had the opportunity to apply it to my immediate teaching context in a way that has proven meaningful for my students, my ESOL department, and myself as a teacher researcher. In this section, I share three cases that reflect the flexible, dynamic, and transformative nature of action research when conducted at different levels within an organization. In addition, I identify the five steps of action research for each case to ensure consistency, validity, and reliability.

\section{Case 1: Benefits for the ESOL Department}

Action research has the potential for impacting departments and schools as a whole. A couple of years ago during a departmental meeting, we (ESOL teachers) realized that the workshops and teacher trainings offered to us did not help in improving our self-identified areas of improvement. Thus, I proposed engaging in action research to identify our instructional areas of growth, a proposed plan of action, and a further evaluation on the effectiveness of that plan of action.

Four ESOL teachers were part of that action research study; I participated in my capacity as teacher researcher. Each teacher-participant identified an area of growth (Step 1-Select area of research) and, because action research is flexible and can be tailored to our specific situation, teachers also identified possible solutions-identified as action plan - that eventually were narrowed down to one solution per teacher. Data were collected through triangulation: (a) face-to-face interviews with teacher-participants, (b) classroom observations, and (c) collection of artifacts in the form of students' notebooks and written materials (Step 2-Collect data). I used the format shown in Table 1 to guide me in the data-collection process and to organize the data gathered from each teacher-participant (Step 3-Organize data). 
Table 1

Example of a Table Used for Triangulating Data

\begin{tabular}{lll}
\hline Research Question & Data Sources & Findings with Explanations \\
\hline $\begin{array}{l}\text { What is/are your reason(s) for } \\
\text { engaging in action research? }\end{array}$ & $\begin{array}{l}\text { What tools are you using to collect } \\
\text { data? Identify three sources per }\end{array}$ & $\begin{array}{l}\text { After data have been collected and } \\
\text { analyzed, explain your findings }\end{array}$ \\
& question & \\
Research Question \#1 & Data Source 1: & Finding: \\
& Data Source 2: & Finding: \\
& Data Source 3: & Finding: \\
\hline
\end{tabular}

After collecting data, I analyzed and interpreted each teacher-participant's data independently and shared the findings with them (Step 4-Analyze and interpret data) to identify opportunities to keep, modify, or improve the original action plan. Last, each teacher-participant implemented modified action plans (Step 5-Take action!). Because of time constraints, we were only able to repeat this cycle twice.

Although four action plans were implemented-an action plan per teacher-participant-one of them was not as successful as expected. However, as a teacher researcher, I understand that all experiences, even failures, serve as reference for further action (Mills, 2007). For the particular action plan that proved unsuccessful, the teacher-participant chose teaching advanced ESOL students to write original text summaries and commentaries, rather than plagiarize them as her instructional area of growth. The teacher-participant explained that it was difficult for her students to summarize stories because they would copy directly from the book. The action plan identified for her was to read texts to students and have them write a summary of the story using their own words and memory (develop auditory proficiency and written skills). The action plan did not prove effective because many advanced ESOL students could not write their own thoughts by just listening to the story. Hence, the teacher needed a different teaching approach that provided sufficient scaffolding for all students equally. Nonetheless, through failure, this action plan unintentionally revealed and assessed the students' listening, reading, and writing proficiencies when analyzing texts.

This departmental action research project was eventually turned into a full-scale qualitative research study because of its importance and impact. It is important to note that action research projects do not have to culminate in published work or even evolve into studies. However, in this particular case, teachers encouraged me to turn this idea into a research study that could be published to share our reality as high school ESOL teachers. See Pentón Herrera (2018) for more information about this action research project that turned into a qualitative research study. 


\section{Case 2: Benefits for the ESOL Teacher}

When I started my career as an ESOL teacher, I had a narrowed understanding of what the word minority truly entailed. During my teacher training, I was taught that ELs are minority students regardless of where they come from. However, through action research, I learned that there are many minorities within the ESOL student population that were not addressed in my teacher preparation programs and are rarely acknowledged in research today.

A few years ago, I engaged in action research to understand why some of my ELs from an all-Hispanic ESOL class were not advancing as fast as their peers (Step 1-Select area of research). Because I was using triangulation, I initially focused on (a) classroom observations, (b) study habits, and (c) family/at-home academic support (Step 2-Collect data), but these data did not yield relevant findings. Because action research is a nonlinear and flexible process, I decided to change my focus to academic background in their native countries (returned to Step 1-Select area of research). As a result, I changed my data collection tools to (a) informal classroom discussions about my students' country of origin and academic background, (b) collection of written artifacts in the form of English and L1 reading and writing activities, and (c) visual representations in the form of activities and assignments that asked students to draw their school back in their native countries (Step 2-Collect data).

To guide me in the data collection process and help organize the data gathered from each teacher-participant, I again utilized a table, similar to Table 1 (Step 3-Organize data and Step 4-Analyze and interpret data). To my surprise, I learned that some of my Hispanic students did not speak Spanish as a first language and some had limited knowledge of the Spanish language. The data gathered, supported by further independent research and readings, revealed that many Hispanic ELs arriving to the United States are not native Spanish speakers because they belong to Indigenous populations in Latin America (Pentón Herrera, 2017). This is also true for other minorities within minority groups within the ESOL population. For example, I have had the privilege of teaching a Chinese student who spoke Uyghur as L1 and ethnically identified as Uyghur, not Chinese. Similarly, I have recently learned from an Ethiopian student that she cannot read and write in Amharic. My Ethiopian student can only read and write in Afaan Oromo, a native language spoken by a minority group of people in Ethiopia and Kenya. Upon further independent research and reflection, I realized that minority students shared a similar past marked by discrimination and mistreatment because they spoke a language that was different to the national language in their countries. In some cases, I witnessed how other ESOL students engaged in behaviours that perpetuated and replicated this discriminatory practice.

Since then, I decided to make my practice learning about my students' first language and native culture, which may be different from their country of origin. Also, I modified my classroom management practices and became more 
cognizant of the role race, ethnicity, social class, language, religion, and gender play in my classroom. As such, I implemented a zero tolerance approach classroom management style with the vision of preventing and stopping any type of prejudice. In addition, I am continuously seeking knowledge and evaluating how I can effectively provide a safe space and welcoming learning environment where my students can reflect on the importance of supporting and advocating for one another (Step 5-Take action!).

\section{Case 3: Benefits for ESOL Students}

The goal of action research is improving the lives of students (Mills, 2007) inside and outside the classroom. For this reason, action research actively involves participants and uses their personal experiences as a source of analytic information that results in practical solutions (Okigbo, Reierson, and Stowman, 2009). After careful analysis and reflection of the materials used in my class, I have come to recently understand that readings in the assigned textbooks focus on everyday situations and interactions that superficially delve into feelings, moral values, and behaviour. For most textbooks and newcomer programs, the primary message is word usage in everyday interaction with peers, teachers, and family members. Hence, these resources do not give high school newcomer ELs the opportunity to critically and meaningfully engage in discussions about behaviour, feelings, and moral values in the U.S. context. For this reason, I engaged in an action research project to gain a better understanding about the relevance of moral and ethical education for high school ESOL newcomers. The ultimate goal of this study is not to solve a problem but to engage in meaningful teacher research to learn from and understand students' perspectives on moral and ethical education as it pertains to English language learning and overall knowledge of the U.S. culture (Step 1-Select area of research).

This action research study has developed in the form of 30-min guided readings at the end of each ESOL class using the book How to Behave and Why by Munro Leaf (1946). For this project, I am interested in exploring the relevance of moral and ethical education in the high school ESOL newcomer classroom through guided reading. Furthermore, I also seek to analyze the potential impact that incorporating reading materials addressing moral values and behaviour has for adolescent ESOL newcomer students learning English. To do so, I have identified the following questions as important:

1. What is the relevance of moral and ethical education in the high school ESOL newcomer classroom?

2. How is guided reading beneficial when teaching moral and ethical education in the high school ESOL newcomer classroom? 
3. What are the participants' personal experiences and reflections of reading and learning about moral and ethical education in the ESOL classroom?

These questions are being answered through student responses during our active guided readings. I am gathering data through my students' comments, interaction with the reading, feedback, and answers to direct questions. I also plan to include a visual elicitation element where students draw a visual representation of a moral value and/or behaviour they have identified as highly important based on their cultural upbringing and/or Leaf's (1946) book (Step 2-Collect data). To organize data, I am planning on using a table similar to Table 1 (Step 3-Organize data). I will collect, analyze, and interpret these data (Step 4-Analyze and interpret data) and make modifications or changes as needed depending on the emerging findings (Step 5-Take action!).

It is my hope that this action research study will give my students the opportunity to fully engage in meaningful interactions that develop their English language skills. Furthermore, it is my vision that my students will find a voice during our purposeful conversations to speak up about topics that are relevant to them and that connect-or not-their upbringing with this new culture and society.

\section{Conclusion - Final Thoughts}

When it comes to improving education and literacy learning, meaningful change happens through entities such as educators and students who are situated within systematic reform at multiple levels (Taylor, Raphael \& Au, 2011). Through action research, educators have the power to become teacher leaders (Rönnerman, 2015) with the knowledge to improve their school and learning environment. Action research conveys a "democratic impulse" (Noffke, 1997, p. 319) inside the classroom that ripples into the entire school. When engaging in action research, teachers give students a voice (Nelson, 2015) with the vision of learning with and from them about the best teaching and learning practices to use in their ESOL context and reality. In this Perspectives article, I explored the opportunities action research offers to K-12 ESOL educators. For this, I shared three action research examples that I have personally used in my practices - at the department, classroom, and student level-and that have contributed to making our ESOL classrooms and classes a better place. It is my hope practitioners reading this Perspectives essay will also become empowered by utilizing and benefiting from action research in their own professional instructional contexts.

\section{Acknowledgement}

I would like to express my gratitude to my wonderful colleague, Margaret Aker, for her words of encouragement and for sharing her wisdom with me during the preparation phase of this manuscript. I would also like to thank all the anonymous reviewers and editors for their comments and time. 


\section{The Author}

Luis Javier Pentón Herrera is an English for Speakers of Other Languages (ESOL) teacher at a public high school and an adjunct professor in TESOL at University of Maryland, Baltimore County (UMBC) and Spanish at University of Maryland University College (UMUC). He is serving on the Maryland Teachers of English for Speakers of Other Languages (MD TESOL) Board of Directors as its president (2018-2019). His research focuses on Bilingual Education, Spanish, ESL/ESOL, Literacy Studies, and Problem-Based Service-Learning (PBSL).

\section{References}

Bolton, G. (2010). Reflective practice: Writing \& professional development (3rd ed.). Thousand Oaks, CA: SAGE.

Burns, A. (2010). Doing action research in English language teaching. A guide to practitioners. New York, NY: Routledge.

Burns, A. (2009). Action research in second language teacher education. In A. Burns and J. C. Richards (Eds.), Cambridge guide to second language teacher education (pp. 289-297). New York, NY: Cambridge University Press.

Calderón, M. (2007). Teaching reading to English language learners, Grades 6-12: A framework for improving achievement in content areas. Thousand Oaks, CA: Corwin.

Custodio, B., \& O'Loughlin, J. B. (2017). Students with interrupted formal education: Bridging where they are and what they need. Thousand Oaks, CA: Corwin.

Echevarría, J., Vogt, M. E., \& Short, D. (2000). Making content comprehensible for English learners: The SIOP® Model. Boston, MA: Allyn \& Bacon.

Elliott, J. (2001). Action research for educational change (7th ed.). Philadelphia, PA: Open University Press.

Gilhooly, D., \& Lee, E. (2016). The Karen resettlement story: A participatory action research project on refugee educational experiences in the United States. Action Research, 5(2), pp. 32-160. doi:10.1177/1476750315625338

Goldberger, H. H. (1920). Teaching English to the foreign born: A teacher's handbook. Bulletin, 1919, No. 80. Department of the Interior. Washington Government Printing Office.

Johnson, A. P. (2012). A short guide to action research (4th ed.). Upper Saddle, NJ: Pearson.

Leaf, M. (1946). How to behave and why. New York, NY: Universe.

Linville, H. A. (2016). ESOL teachers as advocates: An important role? TESOL Journal, 7(1), pp. 98-131. doi:10.1002/tesj.193

Maxwell, T. (2003). Action research for Bhutan? Rabsel III, pp. 1-20.

Meriam, J. L. (1938). Learning English incidentally: A study of bilingual children. Bulletin, 1937, No. 15. Department of the Interior. Washington Government Printing Office.

Mills, G. E. (2007). Action research: A guide for the teacher researcher (3rd ed.). Upper Saddle River, NJ: Pearson.

Nation, I. S. P., \& Macalister, J. (2010). Language curriculum design. New York, NY: Routledge.

Nelson, E. (2015). Opening up to student voice: Supporting teacher learning through collaborative action research. LEARNing Landscapes, 8(2), pp. 285-299.

Noffke, S. E. (1997). Professional, personal, and political dimensions of action research. In M. W. Apple (Ed.), Review of Action Research in Education 22 (pp. 305-343). Washington, DC: American Educational Research Association.

Nugent, G., Malik, S., \& Hollingsworth, S. (2012). A practical guide to action research for literacy educators. Retrieved from https://www.literacyworldwide.org/docs/defaultsource/resource-documents/a-practical-guide-to-action-research-for-literacy-educators. pdf?sfvrsn=abbeaf8e_4

Okigbo, C., Reierson, J., \& Stowman, S. (2009). Leveraging acculturation through action research: A case study of refugee and immigrant women in the United States. Action Research, 7(2), pp. 127-142. doi:10.1177/1476750309103267 
Pentón Herrera, L. J. (2018). ESOL urban high school teachers' perceptions of their instructional strengths and challenges: A qualitative case study. Dialogues: An Interdisciplinary Journal of English Language Teaching and Research, 2(1), pp. 1-21. https://doi.org/10.30617/2.1.2

Pentón Herrera, L. J. (2017). The key is differentiation: Recognizing the literacy and linguistic needs of Indigenous Hispanic students. Literacy Today, 34(6), pp. 8-9.

Pine, G. J. (2009). Teacher action research: Building knowledge democracies. Thousand Oaks, CA: Sage.

Rönnerman, K. (2015). The importance of generating middle leading through action research for collaborative learning. LEARNing Landscapes, 8(2), pp. 33-38.

Sagor, R. (2005). The action research guidebook: A four-step process for educators and school teams. Thousand Oaks, CA: Corwin Press.

Sagor, R. (2000). Guiding school improvement with action research. Alexandria, VA: ASCD.

Staehr Fenner, D. (2014). Advocating for English learners: A guide for educators. Thousand Oaks, CA: Corwin \& TESOL International Association.

Taylor, B. M., Raphael, T. E., \& Au, K. H. (2011). Reading and school reform. In M. L. Kamil, P. D. Pearson, E. B. Moje, \& P. P. Afflerbach (Eds.), Handbook of reading research: Volume IV (pp. 594-628). New York, NY: Routledge.

Volk, K. S. (2010). Action research as a sustainable endeavor for teachers: Does initial training lead to further action? Action Research, 8(3), pp. 315-332. doi:10.1177/1476750309351358 